\title{
SYSTEM MODERNIZATION OF GENERAL SECONDARY EDUCATION IN THE REPUBLIC OF KAZAKHSTAN
}

\author{
MODERNIZAÇÃO DO SISTEMA DE EDUCAÇÃO SECUNDÁRIA GERAL NA REPÚBLICA DO \\ CAZAQUISTÃO
}

\section{MODERNIZACIÓN DEL SISTEMA GENERAL DE EDUCACIÓN SECUNDARIA EN LA REPÚBLICA DE KAZAJSTÁN}

Alma E. Abylkassymova ${ }^{1}$

\begin{abstract}
The article is devoted to the problem of modernization of the school education system in Kazakhstan, in which one of the main sections is the development and implementation of state compulsory standards of general secondary education in all educational organizations, taking into account the various types of educational organizations, and the systematic revision of the education content. All transformations in the country were carried out through the adoption of the Law of the Republic of Kazakhstan "On Education" and state programs of the education system development. At present, State Compulsory Educational Standard -2012 is in effect in the republic, the essence of which is creation of the basis for updating the education content, transition to the 12-year education and the education digitalization. At the same time, the Ministry of Education and Science of Kazakhstan takes part in international studies jointly with the Organization for Economic Co-operation and Development (OECD), as well as TIMSS, PISA, PIAAC, TALIS.
\end{abstract}

Keywords: Modernization. General Secondary Education. State Compulsory Standard. International Studies.

Resumo: $O$ artigo é dedicado ao problema da modernização do sistema de ensino escolar no Cazaquistão, em que uma das seções principais é o desenvolvimento e a implementação de normas obrigatórias estaduais do ensino médio geral em todas as organizações educacionais, levando em consideração os vários tipos organizações educacionais ea revisão sistemática do conteúdo educacional. Todas as transformações no país foram realizadas com a adoção da Lei da República do Cazaquistão "On Education" e programas estaduais de desenvolvimento do sistema educacional. Atualmente, o Padrão Educacional Obrigatório do Estado -2012 está em vigor na república, cuja essência é a criação da base para a atualização do conteúdo da educação, a transição para a educação de 12 anos e a digitalização da educação. Ao mesmo tempo, o Ministério da Educação e Ciência do Cazaquistão participa de estudos internacionais em conjunto com a Organização para Cooperação e Desenvolvimento Econômico (OCDE), além de TIMSS, PISA, PIAAC, TALIS.

\footnotetext{
${ }^{1}$ Abai Kazakh National Pedagogical University. Almaty, Kazakhstan.
} 
Palavras-chave: Modernização. Ensino Médio Geral. Norma Obrigatória Estadual. Estudos internacionais.

Resumen: El artículo está dedicado al problema de la modernización del sistema de educación escolar en Kazajstán, en el cual una de las secciones principales es el desarrollo e implementación de estándares estatales obligatorios de educación secundaria general en todas las organizaciones educativas, teniendo en cuenta los diferentes tipos. de organizaciones educativas, y la revisión sistemática del contenido educativo. Todas las transformaciones en el país se llevaron a cabo mediante la aprobación de la Ley de la República de Kazajstán "sobre educación" y los programas estatales de desarrollo del sistema educativo. En la actualidad, la Norma Educativa Obligatoria del Estado -2012 está vigente en la República, cuya esencia es la creación de la base para actualizar el contenido educativo, la transición a la educación de 12 años y la digitalización de la educación. Al mismo tiempo, el Ministerio de Educación y Ciencia de Kazajstán participa en estudios internacionales conjuntamente con la Organización para la Cooperación y el Desarrollo Económico (OCDE), así como con TIMSS, PISA, PIAAC, TALIS.

Palabras clave: Modernización, Educación Secundaria General. Norma Obligatoria del Estado. Estudios Internacionales.

\section{INTRODUCTION}

The education is a key resource of development and improvement of the well-being of the man, the society and the country on the whole. The education is the major means of successful adaptation of the people in the modern world, the basis of professional successfulness, a prerequisite of the healthy lifestyle, the social mobility and the poverty overcoming. Assurance of connection between the development of the education, science and the technological development of the country is one of major tasks of the education system modernization. A level of training of the population's personnel and the science development must be in unison with the technological and innovation society development.

The education is a major strategic priority of development of a country, and in light of this it was necessary for Kazakhstan to ensure a breakthrough in development of the whole education system in order to improve its quality in accordance with the international standards.

In this connection, in the modern world, it is important to train a competitive specialist, who has a good command of a profession and is able to set and solve the tasks required. Thus, it is essential, from an early age, to develop in children an ability to think analytically and to comprehensively look at the existing situation, and to purposefully develop a child's creative potential and to train his/her leader qualities.

In many respects, the Kazakh education system reflects the Soviet principles of education and upbringing that are based on the teacher's unchallenged leadership and authority and automatic learning of a subject. In many respects the Kazakh secondary education system was aimed at receiving the "grades" rather than on receiving the knowledge. 
Another vestige of the Soviet education system is a slant towards the fundamental knowledge with relative ignoring of an applied aspect. Thus, it is important for us to reorient the values system in the education, where primary focus is on the child. The school and the preschool education organization are supposed to favor the training of the independent personality who looks to the world bravely and who is not afraid to persist in his/her opinion.

The Kazakh education system must be aimed at training a specialist who is competitive in the conditions of the growing globalism in the world. It is necessary to achieve the fact that the Kazakh specialist should not be sidelined and he should be needed in Kazakhstan as well as in any country of the world.

That's why the modernization of the general secondary education system in the Republic of Kazakhstan is oriented to the high final goals - assurance of an equal access to the qualitative secondary education of all the schoolchildren irrespective of their place of residence, and the creation of a national education system aimed at improving the quality of training the human resources, meeting the needs of the personality, the society and the state.

\section{MATERIALS AND METHODS}

2.1. Study materials. For the past years, Kazakhstan has formed the legal framework of the whole educational system, in particular, the general secondary education. The laws "On education" - No. 1153-XII dated January 18, 1992, No. 389 dated June 7, 1999, No. 319-III dated July 27, 2007 and No. 487-IV dated October 24, 2011 (2018) were passed. Apart from that, the state programs, which are aimed at further development of the education system have been implemented and are implemented now. Those are the state program of the secondary education system informatization for 1997-2002, the state program "Education" (2000), the state program of the education development for 2005-2010, the state program of the education development for 2011-2020 and the state program of the education and science development for 2016 - 2019 (2004,2010,2016). A structure of the Kazakh education system is brought to conformity with the International Standard Classification of Education $(2009,2000)$. The above-mentioned binding documents cover quite various aspects of activities of the general secondary education system including the development of the state compulsory standards of all levels of the education, the educational programs, the education plans, etc. $(2018,2019)$.

2.2. Literature review. History of creating the Kazakh school of standardizing the general secondary education for the 11-year school, with account taken of the set goals and the implemented social-pedagogical tasks, is divided into four stages: 1997-1998, 1999-2002, 2008-2010 and 2012-2015. Each of the stages solved certain tasks depending on the dynamics of development of the social phenomena in the society and the education system in the country, a level of the theoretical comprehension and the practical implementation of the newly-created education standards (2019).

Till 1998 the Republic of Kazakhstan had the Soviet education standards, which are adapted to the new 
political and social realities. Thus, in 1997-1998 the subject standards of the secondary education were developed, which were approved by the order of the Ministry of Education, Culture and Public Health No. 456 dated August 21, 1998, which separately considered the issues of teaching the disciplines for schools with the Kazakh and Russian languages of study. The Basic education plan consisted of two parts - the base (invariant component) and the school (variable component). The variable part of the Basic education plan is additional lessons in the primary school, the optional classes in the main school, the main subjects, the applied courses, the optional courses in the main school (2017).

The State Compulsory Educational Standard, which is approved by the order of the Ministry of Education and Science No. 404 dated May 30, 2001, determined the basic content of the primary, basic secondary and general secondary education. The Basic education plan consisted of the state and school education components. A school component of the primary, basic and secondary comprehensive school included the optional subjects, the optional courses, the out-of-school activities. The "Learning the world" subject in the primary school was divided into "Social science" and "Natural science".

The State compulsory standard of the general secondary education, which was approved by the order of the Ministry of Education and Science No. 693 dated September 24, 2002, was developed on 34 school subjects of the primary, basic and senior stages of the school. The standard content became subject-oriented, it determined the basic content of all the stages of the general secondary education system. In the 10-11 forms the studies were divided in two areas: natural-mathematical and social-humanitarian areas (2017).

The Head of state, in his Address to the Kazakh people dated March 19, 2005 (2004), charged the Government with developing the education program for the future. In fulfillment of this assignment, the state program of education development in the Republic of Kazakhstan for 2005-2010 was adopted for the first time (it was approved by the Decree of the Kazakh President No.1459 dated October 11, 2004), where one of the main areas of the education development was a transition to the 12-year secondary general education, where the children have been taught since six years old, and with a system of the specialized and vocationally-orientated education of the senior schoolchildren (2004).

2.3. Study results. In order to implement this program, an experiment on transition to the 12 -year education was organized and carried out, which was started as early as in 2003-2004 academic years. In the first year of the experiment, as experimental platforms, 51 schools from all the Kazakh regions, the cities of Astana and Almaty, was determined. As long ago as the $2004-2005$ academic years, the experiment was enlarged, and the experiment covered 104 schools including the rural and underfilled schools $(2019,2017)$.

In 2003-2007, the experimental work for the primary education was carried out. The work included:

a) a teaching mode - decrease in the teaching load by 2-4 hours (20-27 hours a week); the five-day academic week (1-5 forms); 35-minute lessons in the first form; the ungraded teaching system in the first form; 
b) the teaching content - introduction of a foreign language in the second form, the integrated subject "Science" in the first form, the "Informatics" subject in the second form.

In the 2006-2007 academic years, the first intake of students to the experimental forms finished the primary school. The experiment results were summed up at the republican workshop "Results of the experiment on testing of the educational materials in the primary school", which was carried out in Almaty on May18-19, 2007. As a result, the test textbooks and the additional academic and methodological complex for the primary school were recommended for the use in the mass 12-year school.

In the 2010-2011 academic years, in 51 Kazakh school, the testing of textbooks and the academic and methodological complex for the eight experimental forms started, and in 104 schools the textbooks and the academic and methodological complex continued to be tested for the 5, 6 and 7 forms.

In 2007-2013, the experimental testing was carried out at a level of the basic secondary education (5-10 forms), which includes:

a) a teaching mode - decrease in the teaching load by 2-4 hours (31-34 hours a week); increase in the weekly load volume on linguistic subjects and mathematics;

b) the teaching content - differential and integrated teaching of the sciences fundamentals; strengthening of the communicative directivity of the language teaching; introduction of the integrated subjects - "Natural science" with inclusion of content of the subjects "Self-knowledge", "Geometry (with elements of drawing)" in the 7 form, "Handicraft (with elements of drawing)" in 5-6 and 8-10 forms with inclusion of the basic notions of the market economy, management and marketing, the "Man. Society. Law" subject in the 10 form.

In 2013-2015 the experimental testing continued on transition to the 12-year education at a level of the general secondary education on the basis of the new academic regulatory documents that determine the teaching mode and content, which were adopted by the Ministry of Education and Science. Thus, the weekly teaching load was decreased by 1-3 hours (36-39 hours) in comparison with the 11-year education; the major and non-major subjects (variable component) were determined, which allowed the students to independently choose an individual path of teaching; the criterial system of assessment of the student knowledge was tested. New teaching content was tested, which assured the fundamental character of education and the development of the functional literacy of schoolchildren through enlargement of the national component in studying the basic general subjects.

The experiment, which was carried out by the Ministry of Education and Science, made it possible to draw certain conclusions:

- teaching of children from 6 years old favors their earlier intellectual development and the child's social preparation for study in the basic school;

- in order to preserve the children's health, it is necessary to make changes in the teaching mode towards decrease in the teaching load; 
- $\quad$ it is reasonable to introduce, into the teaching content, the integrated school subjects aimed at forming the children's entirety of world outlook and development of the functional literacy;

- it is necessary to increase the practice-orientation of the education content: increase in a share of the practical training sessions, the laboratory works and tasks, the project-research works oriented to their independent fulfillment by the students;

- it is necessary to improve the knowledge by students of the state language (the Kazakh language) through a functional approach to the teaching;

- early introduction of the "English" subject (in the 2 form) and the "Informatics" subject (in the 2 form) was reasonable;

- it is necessary to implement an individual educational path of students through the pre-profile (8-10 forms) and profile (11-12 forms) training.

\section{DISCUSSION}

In 2010 the new State Compulsory Educational Standard (2019) was developed and approved by the order of the Ministry of Education and Science No. 367 dated July 9, 2010. The Standard consisted of the provisions determining the main requirements for the content of the primary, basic secondary, general secondary education, and all the major subjects were transferred to the school component of the typical education plan.

In the same year the state program of education development for 2011-2020 (it was approved by the Decree of the President of the Republic of Kazakhstan No. 1118 date December 7, 2010) was adopted, where one of the tasks was the transition to the 12-year teaching model (2010).

In connection with amending and supplementing the Law of the Republic of Kazakhstan "On Education" No. 487-IV dated October 24, 2011, a new state compulsory standard of the 11-year secondary education (the primary, basic secondary, general secondary education) was developed, which was approved by the decree of the Kazakh Government No.1080 dated August 23, 2012 (2012).

At present, Kazakhstan implements the education process in the comprehensive schools in accordance with this State Compulsory Educational Standard, which, while preserving the positive experiment of traditional education, laid the groundwork for renewal of the education content with account taken of development of the science and the innovative technologies. The Standard is aimed at implementation of development of the moral and spiritual values of students in the education content; implementation of the pre-profile and profile teaching; development of the functional literacy of students through enlarging the national component of the content; observation of a principle of equal possibilities of students in the conditions of various types and kinds of the education organizations; integration of the subjects of the relevant educational areas; introduction of early study of English and informatics; enhancement of the mathematical disciplines priority in the conditions of developing the innovative-industrial technologies, etc. 
On the whole, State Compulsory Educational Standard -2012 (2012) became a transient phase from the 11-year school to the 12-year education. Thus, the standard provided for a significant change of contentrelated and structural nature. The standard increased requirements for the preservation of the basic content of the education and the observation of optimum correlation of the invariant and variable components, where the invariant component of the content of the secondary education was implemented in the typical education plans, while the variable component was implemented in the working education plans of the education organizations; systematized the subjects content by means of strengthening the inter-subject integration and re-distributing the educational materials by education levels, while enlarging the Kazakh component and strengthening its educational potential; excluded the obsolescent education materials from the program in order to implement new materials reflecting the socio-economic reforms that are carried out in the Kazakh society.

It should be noted that the typical education plan of the primary, basic secondary, general secondary education is developed by levels, languages and areas of the study. The school subjects of the invariant component in all the typical education plans remain unchanged, which ensures the single requirements for the basic content of the secondary education for all the types and kinds of comprehensive organizations. The typical education plan also creates the conditions for implementing the level and profile differentiation of the study on two areas: social-humanitarian and natural-mathematical areas; enlarges the value and activities components of the education content and strengthens its developing and socializing potential; establish the requirements for the education process conditions - for the financial and material support, for the living safety and health production of the students.

The State Compulsory Educational Standard -2012 made it possible to make amendments in and to eliminate shortcomings of the previous State Compulsory Educational Standards, in particular: unjustified distraction of hours of the variable (school and students) component to other subjects introduction (fundamentals of the religious studies, fundamentals of the economic literacy and others); non-conformity of the teaching load hours in the invariant and variant components in the schools with the Kazakh and Russian teaching languages; the absence of possibilities for creating the necessary conditions for the purpose of advanced study of subjects in the comprehensive organizations including the gymnasiums and lycees; the availability of difference in the hours quantity of the variant component in the schools with the Kazakh and Russian languages of study; unreasonable distribution of hours by major subjects of social-humanitarian and natural-mathematical areas; violation of the typical education plans structure (for example, inclusion of the pupils component into the maximum teaching load).

No doubt, the education content is the most important for the general secondary education system, so, let's dwell at length on this issue.

It is known that a level of culture of any people, a nature of their world outlook, the general level of the young generation development, and their readiness for the labor and the life in the society depend on 
the education content. Thus, the education tasks and content systematically change depending on the requirements of social and political life in the state, the condition of its production and science.

At the end of the XVIII century - the beginning of the XIX century the psychological and pedagogical literature acquired terms "material education" and "formal education", on the basis of which two large areas in the sphere of the education content were formed later on. Supporters of the material education believed that a considerable volume of the knowledge, which are transferred to the schoolchildren, must have theoretical and practical applied meaning. According to the formal education supporters' concept, the primary focus must be on development of the students' faculties, their thinking, imagination, memory, will.

Adherents of the two areas ignored the issues of the education content, for which they were severely criticized by progressive scientists and teachers. Thus, Konstantin D. Ushinsky wrote that formal development of the intellect, as it was understood earlier, is a non-existing sign, the intellect is developed only in actual real knowledge. He was against a utilitarian approach to the study of sciences in the school, which is typical of the supporters of the material education. In his opinion, the school is supposed to enrich the man with the knowledge, at the same time, to train the man to the use of these riches. In view of the fact that the school deals with the growing and developing man, whose mental faculties are improved permanently, then the school must meet the present needs and it must lay a store for the future.

The supporters of these theories continue to argue with each other even now. The growing volume of information and knowledge makes some modern foreign teachers think that the school cannot keep up with rapid development of the science and that it is necessary to focus on development of the schoolchildren's intellectual faculties.

At the end of the XIX century - the beginning of the XX century, the pedo-centric education theory gained widespread. The theory was founded by the scientists John Dewey, William Kilpatrick and others. Supporters of this theory considered the education in the light of the child's interests and faculties. They believed that the school task boils down to creation of the favorable conditions for development of the children's bents, interests and faculties. Such educational institutions are changing the school atmosphere. The atmosphere is freer, more movable, is focused on the child and his/her interests. Along with that, European scientists developed other education theories too (2009, 2000, 2000/2003, 2019, 2014, 2018, 2005, 2014, 2003).

Today the education content is one of the main categories of the pedagogy, around and within which the arguments continue for many years, the ideas and conceptions appear, the scientific research is carried out. The education content was the major issue in all the reforms (in any case, in Kazakhstan) in the modern and contemporary education history. It is not necessary to describe all the reforms of the education content. This is on the ground that they had different directivity and differed in a degree of their depth and complexity. The crucial thing, to which it is necessary to pay attention, is that all the efforts to reform the education content was a response to the "modern challenges" that, as expected, are able to efficiently implement the 
ideas planned for the reforms. This is true because since ancient times, information about the world, the society and the man, which was beyond the oral statement and became the written texts, turned into a special essence that lives its own life and that is able to take various forms depending on the conditions and goals of its use. In the education, which was gradually getting the mass education, such information, while being self-structured, took a necessary modern form and became the basic component of a system that is responsible for transferring the cultural experience, which the mankind has accumulated, to the next generations, without which the productive development of the society, the state and a separate man is impossible.

By the education content, the majority of didactics specialists offer to mean:

- a system of knowledge about the nature, the society, the thinking, the technique, the ways of activities, learning of which ensures the formation of the correct picture of the world in the students' consciousness, equips the people with a correct methodological approach to the cognitive and practical activities;

- a system of the general intellectual and practical skills and abilities that are the basis of a lot of specific activities and that ensure the young generation's ability to learn and to preserve the culture;

- $\quad$ an experience of the creative activities, their main features that were gradually accumulated by the mankind in the process of development of the social and practical activities;

- $\quad$ an experience ensuring the ability for further development of the culture;

- $\quad$ an experience of the emotional-value attitude to the world, to each other, which is, together with the knowledge, a condition of appearance of the humanistic persuasions and ideals.

With such understanding, the education content includes all the elements of a social experience, which the mankind accumulated, while the education content is considered as one of the components of the teaching process.

Thus, by the content of the general secondary education, the majority of specialists mean the pedagogically-adopted system of the knowledge, the abilities and the skills, an experience of the creative activities and an experience of the emotional-will attitude, learning of which is designed to ensure the formation of an all-round personality, who is prepared for reproduction (preservation) and development of the material and spiritual culture of the society (2017).

Didactics of the Soviet period of the society development worked out a theory of the general education content, while creatively using the progressive ideas of teachers of the past. The didactics understood the education in a new way and did not reduce it to the knowledge sum. Thus, the Soviet scientist Yuri.K. Babansky defined it in a following way: "The education content is a system of the scientific knowledge, abilities and skills, the mastering of which ensures the comprehensive development of the mental and physical faculties of the schoolchildren, formation of their world outlook, morality and behavior, the 
preparation for the social life and the labor". This approach to defining the education content did not cover fully and did not single out its target components, as formation of the creative and the emotional-value attitude to the world around us.

Another definition of the education content was given by the scientist-methodologist Vladimir S. Lednev, who believes that it is necessary to analyze the education content as an integral system. It should be borne in mind that the education content is not a component of the education in the usual sense of the world. The education content is a special "section" of the education, in other words, this is education, but without account taken of its methods and organizational forms, which are disregarded in this situation. Thus, "the education content is a content of the process of the progressive changes of the personality's features and qualities, a necessary condition of which is activities that are organized in a special way".

The education content is a content of the triune integral process that is characterized, firstly, by the learning of the previous generations' experience, secondly, by the development of the personality's typological qualities, thirdly, by the mental and physical development of the man. As the leading activities are the teaching aimed directly at learning the experience, the education content structure fully reflects the personality structure itself.

In this approach, he considers the main personality's sides as determinantal structures of the general education content, and he considers the learning activities, methods and forms of the teaching as a condition of changing the personality's features and qualities.

By the end of the 1990-s, the education content was structured by 14-17 school subjects. Increase in the subjects number is explained by a great number of the foreign languages studied and by inclusion into the education program of the religious themes, which are traditionally present in the school education in some countries. The general school subjects include the language and literature, mathematics, natural sciences, social sciences, history, geography, art, physical education, handicraft, foreign language. Physics, chemistry, biology, law, philosophy and others are studied towards the senior forms. The senior school became specialized practically everywhere.

At a level of separate school subjects, the same picture exists, but the names and the order of studying separate sections, themes and plots differ in a way. The greatest differences exist in the literary, historical, geographical education reflecting the national, state and geographical specificity of one or another country. According to the authors' assessments, $70-75 \%$ or more of the general secondary education content are identical in all the countries.

Analysis of conceptions of the structure and the content of the educational fields showed that the authors of all the theories were guided, while choosing the content, not so much by peculiarities of a certain age group of students and the pedagogical process logic, as by the interests of development of this area of knowledge, the removal of its internal contradictions. However, orientation only to the logic of the subject knowledge development stipulates the fragmentariness and oddness of the formed knowledge and ways of 
activities, gives rise to the formalism in the students' knowledge, hinders the knowledge transfer from one comprehensive area (or one general subject) to another.

This approach leads to unjustified repetitions in the content of some courses, predetermines a significant disagreement and non-coordination of the content of various educational areas and, as a result, a significant overload of the students (2017).

Because of the fact that, on the whole, Kazakhstan's education system was oriented to its inclusion in the world educational space, this process had a direct relationship to the general secondary education system. For the first time, this goal implementation started in 2011, when the Educational Policy Committee ofthe Organization for Economic Cooperation and Development obliged Kazakhstan to carry out an independent assessment of all the levels of the Kazakh education, for which it was necessary to conduct the national inquiry into competence of the adult population (PIAAC) and the teachers (TALIS). This work was carried out for 6 years, as a result of which the Ministry of Education and Science, jointly with the Organization for Economic Cooperation and Development, performed 7 thematic country reviews. In 20132015 the general secondary education system implemented 2 projects:

1) review of the national educational policy: Secondary education in Kazakhstan (2013);

2) research of the Organization for Economic Cooperation and Development "Review of the policy for making the resources use in the schools more efficient" (2015).

Results of these and other studies made it possible to make amendments in the state program of education development for 2011-2020 and the Law of the Republic of Kazakhstan "On Education" No. 487IV dated October 24, 2011. In this connection, the new state program of the education and science development was adopted for 2016-2019 and the Law of the Republic of Kazakhstan No. 501-V dated April 9, 2016 was passed, according to which, since January 2017, school-leavers started to enter the institutes of higher education according to new rules, and the school exams according to the unified national testing system started performing the functions of exams for entering the institutes of higher education and a system of distributing the state grants. New unified national testing exams started to be developed in the SIT format (System Integration Test). In addition, the Ministry of Education and Science, jointly with other ministries, approved the Road map of the three-language education development for 2015-2020 (2018, 2010, 2016).

A result of activities of the Ministry of Education and Science was the fact that in 2017 Kazakhstan became a full participant of the Educational policy committee of the Organization for Economic Cooperation and Development for the first time.

At the same time, the Ministry of Education and Science took part in the international studies carried out by the Organization for Economic Cooperation and Development, which were universally recognized tools of comparing the education quality between the schools of various countries. Thus, as long ago as 2015 Kazakhstan joined the leader-countries according to the results of TIMSS (assessment of quality of the mathematical and natural-science education of students of 4 and 8 forms). 
Kazakhstan also took part in the study of the functional literacy of fifteen-year-old students of PISA (since 2009). According to the results of PISA-2012 Kazakhstan's rating grew from the 53th to the 49th place. Last time Kazakhstan took part in PISA-2015 (71 countries took part), but the results will be known only at the end of 2019.

In 2019 Kazakhstan takes part in PIAAC-2017 for the first time, which was prepared for 5 years (from 2014 to 2018). In all, 38 countries take part in the study for assessing the adult people's competence.

In 2019 Kazakhstan also takes part in TALIS for the first time, which was prepared for 4 years (from 2016 to 2019). 40 countries took part in the study for assessing the teachers' performance.

These studies results will give an independent assessment of Kazakhstan's education system effectiveness in comparison with the Organization for Economic Cooperation and Development countries. However, for Kazakhstan, the crucial thing is that participation in these studies will help the education system to work for the benefit of Kazakhstan's future by means of providing the qualitative education to everybody (2017).

As stated above, a new program of the education development for 2016-2019 was adopted, where the main task is renewal of the secondary education content (2016). Thus, let's look into the essence of this renewal.

The education content renewal is, first of all, a revision of structure and content of the programs and the methods of teaching. In this connection, the Kazakh pedagogics faces a task of drastic renewal of the school education content on the basis of the advanced world pedagogic experience. The new education model must be focused on development of the functional literacy of schoolchildren, skills of the independent search, the crucial analysis and assessment, the initiative and the ability to find non-standard solutions.

The education content renewal in Kazakhstan is implemented now (2017). Thus, for the children's preparation for receiving the primary education, conditions are created for succession in implementation of the educational programs of pre-school and primary education. Teaching of the alphabet, reading and writing (including "Әліппе" - "АВC book") and early development of children's social, practical life skills and selfteaching skills will be performed in the zero form.

The renewed content continues to be implemented, among other things, in the general secondary education system, which is oriented to forming the students' functional literacy, critical thinking and abilities to use the knowledge and skills in the real life. The education programs include STEM-elements aimed at developing the new technologies, the scientific innovations, the mathematical simulation, the programming, the robotics and the primary technological training. To this end, the additional education programs, the scientific hobby groups and the out-of-school activities are organized. In the senior school, some subjects are taught in English.

In the recent years, in Kazakhstan, the education digitalization has become more intense. Thus, the education management system is created, which includes an electronic data bank of all the process 
participants and the student's electronic profile containing the necessary information in electronic format, and the necessary digital services. For instance, in the secondary education, the electronic school record books and the electronic class registers are used. Apart from that, the exterior digital education services with the use of the Big Data technologies are integrated.

At all the levels, the digital learning content is created. In particular, the electronic educational materials and the electronic libraries with the use of interactive and innovation technologies will be created. The distance teaching will be more accessible through creating the "open universities" on the Internetplatform, developing the content of the electronic teaching resources, integrating the teaching programs between the institutes of higher education and schools. This will create the necessary conditions for promoting the conception "education during the whole life" and for making equal conditions for the students' education in remote rural regions (2017).

It is known that the international and domestic experts indicate the distinctive features of the Kazakh traditional education system, which is focused on, in a greater degree, the ability to remember rather than the ability to think. Thus, in Kazakhstan the subjects were taught with emphasis on the theory, while little attention was paid to their practical application. The educational systems of the Organization for Economic Cooperation and Development states place the emphasis on the competences development. As a result, these countries achieved a great economic success and, above all, through the high competitiveness of the human resources (Finland, South Korea, Japan and others).

In this connection, Kazakhstan has set a goal to achieve a high quality of the education through switching over to a new content of the school education, in other words, Kazakhstan is supposed to switch over from "the knowing man" to "the man who is able to creatively think, act and self-develop", when the teaching is moved from a traditional (knowledge) approach to an innovation (competence) approach.

That's why the Ministry of Education and Science considered it necessary to develop the new State Compulsory Educational Standard (2012). In comparison with the previous standards, the renewed State Compulsory Educational Standard is oriented to building the education model that is based on the results making it possible to assess the student's work and achievements. At the same time, the content renewal implies a deviation from the traditional organization of the educational process and is based on the expected results that are determined by 6 educational areas and reflect the activities aspect, in other words, the students "know", "understand", "use", "analyze", "synthetize", "assess". A clear formulation of the expected results makes it possible to objectively assess the students' academis achievements as well as to raise the students' incentives for developing the abilities and the skills in their study, and to improve the educational process quality.

The new education standard differs from the previous one in some other peculiarities:

- the education programs are based on the competence approach, so they are forming the competences that are built into the basis of the schoolchildren's functional literacy that is necessary for their 
successful socialization in the life;

- while designing the subjects content, the spirality principle is used, which makes it possible to build up the students' knowledge and skills gradually - by themes and forms, with switching over from simple to complicated;

- the primary forms program includes the information-communication technologies subjects with emphasis on their correct and safe use, and the natural sciences subjects for forming the integral environment picture from an early age;

-the three-language education (Kazakh, Russian, English) is implemented, the communicative aspect in teaching the languages is strengthened (teaching of the speech activities: listening comprehension, speaking, reading, writing);

- The all-level education programs are based on the values system of the Patriotic Аct "Мәңгілік Ел" (The Everlasting People) - the Kazakh patriotism and the civilian responsibility, cooperation, openness and respect, labor and creation, education during the whole life.

The "Мәңгілік Ел" ideas were implemented in the Kazakh schools through the academic subjects, the research and out-of-school activities, the additional education and the elective courses. Their content is aimed at forming the students' spiritual and moral qualities, the Kazakh patriotism and the desire to translate the national idea of "Мәңгілік Ел" into reality, and at developing the students' national consciousness, tolerance and ability to communicate in the conditions of inter-ethnic and intercultural variety in the society.

The Address by the Head of State to the Kazakh people dated January 31, 2017 "The third modernization of Kazakhstan: global competitiveness" (2017) says that it is necessary to narrow the gap in the education quality between the urban and rural schools. In order to implement this assignment, at present, the work is carried out between the Republic of Kazakhstan and the International Bank of Reconstruction and Development on the project "Modernization of secondary education" for 2018-2022. The project is aimed at improving the quality of the secondary education system, supporting the education modernization and increasing the access and the equality in the education.

The project contains three components.

Component 1 . Support of the secondary education modernization.

This project provides for a package of measures required for renewing the secondary education content that is implemented on the pilot basis, which implies the bringing the students' assessment system to conformity with the renewed content; the methodological support of schools, including by means of developing and supplying the learning and methodical materials, the comprehensive and education programs, the assessment system; re-training of the testing centers employees, the educational literature experts, the faculty staff of institutes of higher education, including the English language; renewal of the material and technical base of seven pedagogical institutes of higher education with the multimedia equipment. 
Component 2. Support of the vulnerable schools for reducing the inequality in the secondary education system.

This component is aimed at fitting the rural comprehensive schools with the multimedia equipment (16000 complete sets); improving the professional skills of teachers and heads of rural schools; developing the inclusive education through elaborating a model of special education programs to teach the mentally challenged children and the methodical guides for teachers.

Component 3. Support of the citizens' involvement, monitoring and assessment, assistance in the project implementation.

This component provides for the independent monitoring and the assessment of the project implementation through an independent outside organization, consultative-explanatory measures, including the processing of complaints, and the support of public forums.

It will be possible to speak about this project implementation results only after the lapse of three years.

\section{CONCLUSION}

The main goal of the education renewal is to build up the socio-economic potential, to overcome the lag in separate economic sectors, to develop the population's spiritual culture, to enhance the social and professional mobility of the personality. The true, main sense of the school reform is in the system and systematic renewal of the general secondary education. It is possible to switch over to the new education quality only in this way: to the personality-oriented education, to the educational programs variety, the development of academic freedoms, the formation of the legal, psychological, economical and ecological culture of the students.

In respect to the school, these guidelines, which are general for the whole education, are transformed to tasks of developing the new qualities of young people - their all-round development, creative faculties, abilities and skills, self-education, the formation of readiness and capacity to be adapted to the permanently changing social conditions of the society life, etc.

Thus, the education content renewal is aimed at fulfilling the main task of the education system - to improve the education quality and to switch over from the paradigm "education for the whole life" to the paradigm "education through the whole life". Apart from that, the authors' analysis of modernization of the general secondary education system in Kazakhstan showed that as the general secondary education is improved, the education content in the secondary school is strengthened and improved, which makes it possible to teach the Kazakh schoolchildren at the modern level, in accordance with tendencies of the world educational process development.

\section{REFERENCES}

Law of the Republic of Kazakhstan "On Education" dated July 27, 2007 No. 319-III (as amended and supplemented as of 04.07.2018). - Astana, 2018. - 197p. [Zakon Respubliki Kazakhstan “Ob 
obrazobanii" ot 27 iulya 2007 goda No. 319-III (s izmeneniami i dopolneniami po sostoyaniu na 04.07.2018). - Astana, 2018. - 197s.]

State program of the education development in the Republic of Kazakhstan for 2005-2010 // Approved by the Decree of the President of the Republic of Kazakhstan dated October 11, 2004 No. 1459. [Gosudarstvennaya programma razvitia obrazobvania v Respublike Kazakhstan na 2005-2010 gody // Utverzhdna Ukazom Prezidenta RK ot 11 oktyabrya 2004 goda No.1459.]

State program of the education development of the Republic of Kazakhstan for 2011 - 2020 // Approved by the Decree of the President of the Republic of Kazakhstan dated December 07, 2010 No.1118. [Gosudarstvennaya programma razvitia obrazobvania Respubliki Kazakhstan na 2011 2020 gody // Utverzhdna Ukazom Prezidenta RK ot 7 Dekabrya 2010 goda No.1118.]

State program of the education and science development of the Republic of Kazakhstan for 2016 2019 // Approved by the Decree of the President of the Republic of Kazakhstan dated March 1, 2016 No. 205. [ Gosudarstvennaya programma razvitia obrazobvania i nauki Respubliki Kazakhstan na 2016 - 2019 gody // Utverzhdna Ukazom Prezidenta RK ot 1 marta 2016 goda No. 205]

Address by the President of the Republic of Kazakhstan to the Kazakh people "Competitive Kazakhstan, competitive economy, competitive nation". - Astana, March 19, 2004 [Poslanie Prezidenta Respubliki Kazakhstan narodu Kazakhstana "Konkuretosposobnomu Kazakhstanu, konsurentosposobnoi ekonomike, konsurentosposobnoi natsii". - Astana, 19 marta 2004 goda.]

State Compulsory Secondary Education Standard (начального, basic secondary, general secondary education) //Approved by the Decree of of the Government of the Republic of Kazakhstan dated August 23, 2012 No. 1080. [Gosudarstvenny obscheobyazatelny standart srednego obrazovania (nachalnogo, osnovnogo srednego, obschego srednego obrazovania) //Utverzhden postanovleniem Pravitelstva RK ot 23 agusta 2012 goda No. 1080.]

Address by the Kazakh President "The third modernization of Kazakhstan: global competitiveness". - Astana, January 31, 2017. [Poslanie Prezidenta Kazakhstana "Tretia modernizatsia Kazakhstana: globalnaya konkurentosposobnost". - Astana, 31 yanvarya 2017 goda.]

National summary sheets on education systems in Europe and ongoing reforms. Finland, august 2009. Access mode: http: // www.eurydice.org.

FEIMAN-NEMSER S., NORMAN P. J. Teacher education: From initial preparation to continuing professional development. In: Moon B., Ben-Peretz M., Brown S.A. Routledge International Companion to Education. - London: Routledge, 2000. - Pp. 732-755.

ABYLKASSYMOVA A.E., KALNEY V.A., SHISHOV S.E. International trends in the formation of continuing teacher education for training personnel relevant to the digital economy. Scientific and Practical Journal "Vestnik RMAT", n. 3, p. 28-39, 2018

ABYLKASSYMOVA A.E., RYZHAKOV M.V., SHISOV S.E. A Retrospective Analysis Of The Reforms Of The Content Of General Secondary Education: How They Contribute To The Consolidation Of Public Consciousness. Modern Journal of Language Teaching Methods, v. 9, n. 1, p. 331-338, jan., 2019. 
RYZHAKOV M.V., ABYLKASSYMOVA A.E., SHISOV S.E. About The Lessons on The Development of State Educational Standards in The Russian Federation and The Republic of Kazakhstan. Modern Journal of Language Teaching Methods, v. 9, n. 1, p. 625-636, jan, 2019.

ABYLKASSYMOVA A.E., RYZHAKOV M.V., SHISOV S.E. Modern tendencies of development of continuous pedagogical education. Monograph. Almaty: Atamura, 2017.

Approaches to the evaluation schools which provide compulsory education. Finland 2000/2001. Evaluation of Schools providing Compulsory Education in Europe. Country Reports. 20 p.- Access mode: http://www. eurydice.org.

KOWALCZUK-WAEDZIAK M., et. Rethinking Teacher Education for the 21st Century Trends, Challenges and New Directions Opladen: Berlin \& Toronto, 2019.

SCHRATZ M. The European teacher: transnational perspectives in teacher education policy and practice. - CEPS Journal, v. 4, p. 11-27, 2014.

BEKBOEV I.B., MIROSHNICHENKO L.P., SIRMBARD S.R. The main areas of modernizing the education system and training the scientists in the European countries. Higher education of the Kyrgyz Republic, n. 3. 2008.

BOLOTOV V.A. The past, the present and the possible future of the Russian system of the education quality assessment. - Zh.: Education issues, n. 3, 2018.

ZEER E.F., PAVLOVA A.M., SYMANYUK E.E. Modernization of professional education: competence approach. - M.: Moscow psychological and social institute, 2005. - $216 \mathrm{p}$

NIKOLAEVA A.D., GOLIKOV A.I., BARAKHSANOVA E.A. Strategic priorities of modernization of the continuous pedagogical education system. Modern problems of science and education, n, 4, 2014.

PHILIPPOV V.M. Modernization of the Russian education. - M.: Enlightenment, 2003.

\section{$\underline{\text { ABOUT THE AUTHOR }}$}

\section{Alma E. Abylkassymova}

Doctor of pedagogical sciences, professor, honored worker of the Republic of Kazakhstan, corresponding member of the National academy of sciences of the Republic of Kazakhstan, academician of the Russian academy of education, director of the Center for development of pedagogical education - head of the chair for methods of teaching mathematics, physics and informatics. E-mail: aabylkassymova@mail.ru

ORCID: https://orcid.org/0000-0003-1845-7984

Received on: $02 / 15 / 2020$

Approved on: 03/25/2020

Published on: 04/02/2020 